\title{
Internet Financial Reporting: Disclosure About Companies on Websites
}

\author{
Tehmina Khan \\ Victoria University, Australia
}

\begin{abstract}
The Internet has emerged as a medium of communication of financial reporting information by companies since the mid to late nineties. There are various aspects of Internet based financial reporting that are different from the traditional hard copy presentation. These factors include the actual mode of presentation and, the process of access to the information, that is accessing a company's website rather then the hard copy version of the financial reports. Various bodies mentioned in this paper have made recommendations to improve financial reporting disclosure online. There is lack of uniformity regarding financial reporting disclosure between companies world wide. This is in relation to various aspects of financial reporting. The three aspects of financial reporting disclosure investigated in this paper include: Fundamental reporting elements, Corporate Social Responsibility reporting elements and Corporate Governance elements. Four samples of companies were selected for comparison regarding financial reporting disclosure. These include: diversified companies, hotels, companies listed on the London and the New York Stock exchanges. It was found that 31 percent of the sample companies did not have a website. The diversified companies had the highest percentage of financial reports on their websites, with the hotels having the least presence of financial reports on their websites. The companies listed on the London Stock exchange had more financial reports available on their websites as compared to the ones listed on the New York Stock Exchange. The item that was least disclosed was the Analysts' Coverage item. Twenty percent of the sample companies with financial reports did not have accompanying audit reports. This is a cause for concern because all companies are required to have audit reports with their annual financial reports under national and international regulatory requirements. Out of the financial statements, the least disclosed statement was the Shareholder's Equity statement. It was found that the disclosure was varied from none to adequate but not 100 percent complete in regards to the three types of financial reporting disclosure mentioned above. It was also found that most companies were not following the best practice guidelines as recommended by various national and international bodied therefore having a negative impact on the implementation of the fundamental qualitative characteristics of accounting information being reliability, understandiblity, completeness, timeliness and verifiability of information. It is important for companies world wide to adopt a uniform approach to financial reporting on the Internet in order to make decision making by users a more informed process.
\end{abstract}

\section{Introduction}

Copyright (C) 2007 Victoria University. This document has been published as part of the Journal of Business Systems, Governance and Ethics in both online and print formats. Educational and non-profit institutions are granted a nonexclusive licence to utilise this document in whole or in part for personal or classroom use without fee, provided that correct attribution and citation are made and this copyright statement is reproduced. Any other usage is prohibited without the express permission of the
The Internet offers the potential for companies to reach a wider range of users due to the availability of financial reporting information on the websites without time limits, or boundaries. According to Cucuzza and Cherian (2001) E-Business tools are providing new ways to communicate vast quantities of information, in an environment where information flows continuously and without hindrance. 
The issue that arises from using the Internet for presentation of financial reporting information, then, is the lack of uniformity between companies in regards to the nature and detail of information provided. A major contributory factor is the lack of a coherent framework for Internet based financial reporting, that all companies using the Internet can follow, regardless of country origin, national requirements or company preferences in the selection of information to be presented on a website.

According to Litan and Wilson (2000) the transition from hard copy to Internet usage for presentation of financial information requires major changes in the legal and regulatory framework in which economies function. Litan and Wilson ( 2000) have also proposed that utilising the Internet capabilities more efficiently should generate financial reporting that is forward looking, describing not only historical cost, but also providing a more accurate picture of the organisation's current and future prospects. This is a strong statement since Litan and Wilson (2000) are implying that the Internet would generate good quality financial reporting based on better technical usage of the Internet. The question that needs to be addressed is whether companies actually do provide good quality financial reporting on the Internet? Or at least provide the same scale and scope of information that is expected in traditional, hard copy versions.

\section{Use of the Internet for Financial Reporting}

A range of research has been conducted in the past in regards to the percentage of companies using the Internet for financial reporting purposes. Cook (1999) has provided a summary of the research conducted in this regards by various authors, summarised in Table 1.

Table 1 Cook's Summary of Surveys on Companies' Use of the Internet

\begin{tabular}{|c|c|c|c|}
\hline Study & Companies Surveyed & Web Sites & Financial Reporting \\
\hline CAROL survey (1999) & $\begin{array}{l}\text { Top } 1000 \text { companies in } \\
\text { Europe }\end{array}$ & $67 \%+$ & $80 \%$ ( of those with websites) \\
\hline $\begin{array}{l}\text { Debrecency and } \\
\text { (1998A) }\end{array}$ & $\begin{array}{l}45 \text { companies from Dow Jones } \\
\text { Global Index }\end{array}$ & $98 \%$ & $80 \%$ ( annual reports) \\
\hline Hussey et al. (1998) & FTSE-100 companies & $91 \%$ & $63 \%$ ( of websites that were contactable) \\
\hline Lymer (1997) & Top 50 companies in the U.K. & $92 \%$ & $60 \%$ \\
\hline Grey and Debreceny (1997) & U.S. Fortune 50 companies & $98 \%$ & $68 \%$ \\
\hline Tallberg and Lymer (1997) & $\begin{array}{lcl}\text { All } \quad 72 & \text { listed } & \text { Finnish } \\
\text { companies }\end{array}$ & $90 \%$ & $69 \%$ \\
\hline Wildstrom (1997) & $\begin{array}{l}\text { Companies on Business } \\
\text { week } 50 \text { list (U.S.) }\end{array}$ & $94 \%$ & $78 \%$ \\
\hline $\begin{array}{lll}\begin{array}{l}\text { Marston } \\
(1996)\end{array} & \text { and } & \text { Leow } \\
\end{array}$ & FTSE 100 companies & $63 \%$ & $45 \%$ \\
\hline Petravick \& Gillett 1996 & Fortune 150 companies & $69 \%$ & $53 \%$ \\
\hline
\end{tabular}

Source: Cook (1999)

There has been a trend of increase in the use of the Internet for financial reporting from the earliest period mentioned 1996 to 1999 from $45 \%$ to $80 \%$.

A survey conducted by Lymer et al. in 1999, found that 86 percent of the corporations surveyed had a website. 268 out of the 410 companies had corporate information on their website and 62 percent of the corporations made some form of financial disclosure on their websites. In the 1998 survey, by Marston \& Leow (1998), which involved the analysis of websites of the 100 FTSE companies, $63 \%$ of the sample companies had web sites or home pages on the Internet. Out of these 63, 45 (71 percent) disclosed financial information, and 34 (54 percent) disclosed detailed annual reports.

The aim in this study has been to conduct a similar study of corporations' websites, in order to determine the level of disclosure and transparency in relation to financial reporting.

The financial reporting elements investigated have been classified into three main categories after investigating a general category of whether the companies have websites or not, whether they have financial reports on their websites or not and whether they have an analysts' coverage section or not. 
The three main categories are: fundamental reporting elements such as financial reports, corporate social responsibility reporting elements and corporate governance reporting elements.

In order to ensure a better and more informed disclosure, various national and internal bodies have made recommendations and provided guidelines for companies in relation to online financial reporting. These recommendations are provided as follows.

This is important in order to compare what is recommended versus what is actually presented on the websites.

\section{Recommendations by Bodies for Optimal Financial Reporting on the Internet}

Various bodies have made pronouncements and recommendations to make Internet financial reporting more reliable, of better quality and useful. These bodies include the International Accounting Standards Board (IASB), Webtrust, COB (France) and FASB (United States).

\section{International Accounting Standards Board (IASB)}

According to the guidance issued by the IASB, published in a report prepared by Lymer et al (1999) the financial reports provided online should have the same scale and scope as traditional hard copy versions, otherwise any information lacking or additional information should be disclosed as such.

The guidance requirements also include the following factors:

1. Boundaries should be clearly set out between audited financial statements and related financial information,

2. Users should be notified of significant changes to the website,

3. Internal link integrity should be assured at all times,

4. External link integrity should be assured to an optimal level,

5. All security provisions should be made to ensure integrity of the data,

6. Errors existing should be clearly identified,

7. Multiple GAAP reports should be presented on the company's website,

8. GAAPs and IAS based financial reports should be clearly identified,

9. Supplementary financial information should be made widely available for the benefit of the stakeholders,

10. If the main language of the stakeholders is different, the information should be presented in multiple languages for the wider use,

11. All price sensitive data should be available as soon as reporting restrictions have been complied with on the website,

12. Data provided by others should be clearly identified,

13. Contact points should be given for further information. (Lymer et al. 1999).

As demonstrated above the aim of the IASB report has been to provide more transparent, usable and secure financial information online. There is also an emphasis on provision of complete information that can be utilised by multiple users. Point 12 emphasises the importance of segregating and presenting third party information in such a way that users will be able to determine that this information is not from the primary source, that is the company. One of the reasons for this recommendation could be the liability and accountability aspect of information. 


\section{Web Trust}

The Web Trust program undertaken by the AICPA and the Canadian Institute of Charted Accountants also incorporates security issues as the responsibility of the issuing organisation. There are six standards incorporated in the program including a standard dealing with security. The Security standard assures that the website of the organisation should maintain effective controls and practices to address security matters such as encryption of private and confidential customer information, protection of information once it reaches the site, protection against virus transmission, and customer approval before the site stores, alters or copies information on the customer's computer. A further standard on nonRepudiation assures that the site discloses its practices for non-repudiation, complies with such controls and appropriate records to provide reasonable assurance that the authentication and integrity of transactions and messages received electronically are provable to third parties in conformity with its disclosed non-repudiation practices. A third standard on Availability assures that the site discloses its availability practices, complies with such practices and maintains effective controls to provide reasonable assurance that its e-commerce systems and data are available as disclosed (WebTrust 2006).

\section{Commission des- Operations de Bourse (COB)}

The Commission des -Operations de Bourse (COB) is a public independent regulatory agency in France whose mission is to ensure the protection of investors whether their investments are in securities or other financial products involving public offerings. $\mathrm{COB}$ also emphasises the adequacy of the information given to investors and the proper operation of the markets in financial instruments. COB issued a press release regarding the use of the Internet for distribution of financial information by listed companies in May 1999.

Some of the recommendations are listed below:

1. The information provided by a company on its web site should be accurate, precise and sincere. Any links to additional sites should be easily identifiable. Disclaimers on the website of the company should be clearly identified with all contents of the website to which they hold.

2. If there are any errors on the website they should be quickly identified, a warning should be issued and the mistake should be rectified.

3. Documents listed on the website should be clarified as either complete, or as summaries or extracts. With summaries and extracts reference should be made as to where the whole document can be obtained.

4. The source of the information should be clearly identified and mentioned if it's from a public source and if it has been audited or not and if there are comments made on the document they should be referenced. Outside information should not be included on the website without the author's permission. Financial research regarding the company should be carefully evaluated before being added to the website. It should be presented honestly and should not mislead the public. Extracts of the research should not be presented in such manner as to favour the company and the details of the author and the full research should be provided (Commision desOperations de Bourse 1999).

\section{FASB Institutional Framework}

The United States standards setting body, Financial Accounting Standards Board (FASB) has provided a more precautionary approach to be taken by companies on their websites. According to Financial Accounting Standards Board (2000):

Companies should provide cautionary disclaimers accompanying everything presented on the web page including forward-looking statements and speeches, not provide links to analysts' websites, include full sets of statutory reports and notes, avoid duty to update disclosures by putting disclaimers against updated information and update security measures. 
Auditors are not required under the FASB Framework to read information contained in electronics sites, or to consider the consistency of other information in electronic sites with the original documents' (Gray \& Debreceny 2001). In Australia, this added responsibility has been recommended to be taken as additional engagement by the auditor, if the auditor may choose to study the information presented by companies on their websites.

\section{Methodology}

There were four samples of companies that were investigated for the purpose of this study. These included twenty-six diversified companies, representing twenty-three countries, seventy-eight hotels, representing thirty countries, fifty-six companies listed on the New York Stock Exchange, representing forty three countries and seventeen companies listed on the London Stock Exchange, representing seventeen countries, generating a total of 177 companies. SPSS was used to create a data base of twenty four variables (defining financial reporting disclosure online) in relation to the sample companies. The data collection period was from January to March 2005 inclusive.

Kaye and Yuwono (2002) have asserted that the specific objective of the conglomerates or diversified companies is to increase long-term value for shareholders. Kaye and Yuwono (2002) have stressed that a major factor influencing this goal is to make reporting more transparent. Therefore it would be expected that diversified companies would have extensive financial reporting disclosure on their websites.

The diversified group of companies was therefore selected to represent the opposite of the Hotels and Motels, in that these companies emphasise the transparency of financial reporting. The diversified group represented twenty-three countries. The Hotels and Motels were assumed to use their websites for other purposes than financial reporting, such as the promotion of their products and services.

The third sample group was derived from non-U.S.companies listed on the NYSE, representing fortythree countries. Reasons that this group was selected included: The NYSE is the largest stock exchange in the world, it has the most extensive disclosure requirements, it requires use of U.S.GAAP or reconciliation to the U.S.GAAP and it has extensive corporate governance disclosure requirements. Therefore the assumption made was that companies listed on the NYSE would have extensive transparency and disclosure due to the regulatory requirements, regardless of the country of origin.

The fourth sample group includes non-British companies listed on the London Stock Exchange from seventeen countries. The reasons that this group was selected included: it is the second largest stock exchange in the world and the disclosure requirements are less rigorous then the NYSE. It would be an adequate group for comparison regarding differences in disclosure levels, in comparison to the NYSE.

The initial approach was to send a questionnaire to companies requesting information in relation to the financial reporting disclosure. The response rate was 40 percent. These were not direct responses to the questionnaire, rather statements suggesting that the answers to the questions addressed in the questionnaire were answered in the company's website and that the researcher should study the company's website for the information required. This lead to the investigation of the companies' websites as well as the Internet in order to attain information in relation to the variables mentioned in Table 2, 3, 4 and 5 .

Table 2 Variables investigated in the Study: General

\begin{tabular}{|l|l|l|}
\hline $\begin{array}{l}\text { Variable } \\
\text { number }\end{array}$ & Variable Title & \multicolumn{1}{c|}{ Explanation } \\
\hline 1 & Website & Did the company have a primary website? \\
\hline 2 & $\begin{array}{l}\text { Secondary } \\
\text { websites }\end{array}$ & $\begin{array}{l}\text { If the company did not have a primary website, then were secondary websites } \\
\text { available with financial data on the company, accessible via the search engine? }\end{array}$ \\
\hline 3 & Annual Report & $\begin{array}{l}\text { Did the company have annual reports/ interim reports/other documents with } \\
\text { financial data accessible on the website? }\end{array}$ \\
\hline
\end{tabular}




\begin{tabular}{|l|l|l|}
\hline 4 & Analyst Coverage & $\begin{array}{l}\text { Did the company have a link to a list of analysts providing coverage on the } \\
\text { company? }\end{array}$ \\
\hline
\end{tabular}

Table 3 Variables investigated in the study: Fundamental Reporting

\begin{tabular}{|l|l|l|}
\hline 8 & Audit Rep & Did the company have an audit report online? \\
\hline 9 & Income St. & Did the company have an Income statement? \\
\hline 10 & $\begin{array}{l}\text { Shareholder's } \\
\text { equity st. }\end{array}$ & Did the company have a statement of changes in shareholder's equity? \\
\hline 11 & Balance Sheet & Did the company have a Balance Sheet? \\
\hline 12 & CFS & $\begin{array}{l}\text { Did the company have a Cash Flow statement as part of its financial reporting } \\
\text { online? }\end{array}$ \\
\hline 13 & Notes & Did the company have notes accompanyinhg the statements on its website? \\
\hline
\end{tabular}

Table 4 Variables investigated in the study: Corporate Social Responsibility (CSR) Reporting Elements

\begin{tabular}{|l|l|l|}
\hline 16 & CR REP1 & $\begin{array}{l}\text { This variable incorporated any information provided on employees, work } \\
\text { conditions, value added statements. }\end{array}$ \\
\hline 17 & CR REP2 & This variable incorporated environmental policies disclosed online \\
\hline
\end{tabular}

Table 5 Variables investigated in the study: Corporate Governance Reporting Elements

\begin{tabular}{|l|l|l|}
\hline 20 & DIR BIO & Did the company provide director biographies? \\
\hline & CG Policies & Did the company display corporate governance policies in its annual report? \\
\hline 21 & COMM & $\begin{array}{l}\text { Did the company have any information on Corporate Governance committees on } \\
\text { its website }\end{array}$ \\
\hline 23 & COMM CH. & Did the company provide any committee charters? \\
\hline 24 & C of Conduct & Did the company provide a code of conduct? \\
\hline
\end{tabular}

\section{Research Findings}

The findings indicated that 31 percent of the companies formulating the sample did not have a website at all, of which 78 percent were hotels. 62 percent of the companies that did not have a primary website did have some information available on secondary websites such as "Yahoo Financials" and "Bloomberg".

In regards to annual reports, 86 percent of diversified companies, 46 percent of hotels, 79 percent of companies listed on the NSYE and 92 percent of the ones listed on the London stock exchange had financial reports present on their websites. These results were expected for the diversified companies and the hotels, since it was assumed that hotels would use their websites for other purposes than presentation of financial reports. Kaye and Yuwono's (2002) point of view that diversified companies' success has been on making reporting more transparent was also supported by the findings in this research.

The results for the NYSE and the London stock exchange listed companies were more surprising since it was assumed that companies listed on the NYSE would be more transparent (due to rigorous disclosure requirements) and would thus be more probable to include financial reports on their websites. On the contrary there were 13 percent less companies with financial reports on their websites listed on the NYSE, as compared to the ones listed on the London stock exchange.

The results regarding the remaining variables in relation to each sample are presented in Table 6. 
Table 6 Percentage of companies with disclosure of variables

\begin{tabular}{|l|l|l|l|}
\hline Variable & Total & Variable & Total \\
\hline $\begin{array}{l}\text { Analyst } \\
\text { Coverage }\end{array}$ & $6.5 \%$ & Audit Report & $80 \%$ \\
\hline Income St. & $97 \%$ & $\begin{array}{l}\text { Shareholder's } \\
\text { Equity St. }\end{array}$ & $75 \%$ \\
\hline Balance Sheet & $100 \%$ & CFS & $90 \%$ \\
\hline Notes & $62 \%$ & CR REP1 & $72 \%$ \\
\hline CR REP2 & $48 \%$ & DIR BIO & $89 \%$ \\
\hline CG Policies & $34 \%$ & COMM & $77 \%$ \\
\hline COMM CH. & $71 \%$ & C of Conduct & $72 \%$ \\
\cline { 2 - 4 } & ArtInc & $17 \%$ & \multicolumn{2}{|l}{} \\
\cline { 2 - 3 } & &
\end{tabular}

Table 6 provides a valuable insight into the nature of financial reporting on the Internet by companies. It supports the notion that the level of disclosure is varied in regards to different elements of financial reporting. This variance exists regardless of the requirements under regulatory frameworks.

\section{Analyst Coverage}

Analyst coverage is a recent addition to financial reporting. A survey conducted by Thomson Financial Publishing revealed that $76 \%$ of all investors say they are "most influenced" by an analyst report (http://www.investrend.com/iciresearcharticle.htm, accessed July 2004). There are some important issues in relation to analyst reports as part of the financial reporting online. One of the issues is the ability to distinguish between 'legitimate' research announcements and 'promotional clutter'. One-way of confirming that third party opinion, as part of the company's financial data is 'legitimate' is for the company to have a list of analysts that the user can rely on for additional information. On the other hand, conservatism would encourage the company not to have any third party links at all on its website. The extremely low percentage of companies with this information disclosed would suggest support for the conservatism approach, where companies would not even provide a list of analysts in order to minimise the risk of litigation.

\section{Audit Reports}

Twenty percent of the companies with annual reports did not have accompanying audit reports. Companies are not only required to provide audit reports with their annual reports, according to the IASB requirements, the IASB as well as the other regulatory frameworks have also emphasised for the companies to ensure that they segregate audited information from un-audited information on their websites. The companies also need to ensure that there is no implication that information is audited when it's not (Lymer et al. 1999). Such degree of clarification in the audit reports was not found with any of the sample companies.

\section{Financial Statements}

Out of the reports considered fundamental under the IASB requirements to be included in the annual reports and interim reports, the Shareholder's Equity Statement had the least presence as part of companies' websites. Notes to the statements were also missing for forty percent of the companies.

\section{Corporate Social Responsibility (CSR) Reporting}

According to the World Business Council for Sustainable Development (WBCSD) Corporate Social Responsibility is defined as 'The commitment of business to contribute to sustainable economic development, working with employees, their families, the local community and society at large to improve their quality of life' (KPMG Global Sustainability Services 2005). 
Choi \& Meek (2005) have described 'Social Responsibility Disclosures' as measurement and communication of information about a company's influence on employees' welfare, the community, and the environment. Wilson \& Lombardo (2001) as well as Choi \& Meek (2005) have referred to CSR as incorporating the Triple Bottom Line Reporting, concentrating on Economic, Social and Environmental Reporting. Wilson \& Lombardo (2001) have also mentioned that shareholders are demanding companies to include environmental reporting in the annual reports; Internet based financial reporting being partially responsible for this shift in demand. The reason presented is the increase in the amount of stakeholders being interested in corporate financial data, thus the wider scope of interested parties, including users placing a major emphasis on environmental reporting.

In regards to information provision on employees, work conditions, gender proportions, community programs and other type of information relating to the affect on employees' welfare and community, represented by the variable CR REP1, the disclosure was much higher than disclosure on environmental policies, represented by the Variable CR REP2.

KPMG (2005) found that 64 percent of Global 250 and 41 percent of National from the top 250 Fortune 500 companies issued Corporate Social Responsibility (CSR) reports in 2005.

The average for CR REP 1 and CR REP 2 corresponds with the results obtained by KPMG for the Global 250 companies.

\section{Corporate Governance Reporting}

In relation to the corporate governance items, the variables investigated are based on the work done by Radner (2002) incorporating "Best Practices in Online Corporate Governance Disclosure." Radner (2002) generated a checklist, which is based on the Sarbanes Oxley Act (SOX) of the U.S. The average disclosure level for the Corporate Governance items was found to be around 60 percent, with the least presence of Articles of Incorporation and Corporate Governance policies. Jubb, Smith and Haswell (2002 p 939) have defined Articles of Incorporation as "The rules that govern the rights and obligations of a company's members... a company's by-laws". The reason that companies may not include the Articles of Incorporation in their corporate governance disclosure is because this document is produced and filed in the initial stages of incorporation. None the less it has important information such as details on shareholder meetings, roles and responsibilities of the Board and details on the nature of shares issued and should be disclosed.

According to Radner (2002) web based disclosure of corporate governance policies is a NYSE listing requirement. It was found that some of the companies provided detailed information on the differences between the corporate disclosure requirements in their countries, the disclosure requirements of the stock exchange on which they were listed and the actual practice by the company. Majority of the companies ignored the disclosure of the corporate governance policies including the mandatory NYSE listing requirements of fulfilling three conditions applicable to listed companies.

According to section 303 A listed companies must have an audit committee; listed companies must provide disclosure regarding the differences between the national and NYSE listing requirements and a statement by the CEO that he or she is not aware of any violation by the company of NYSE corporate governance listing standards (http://www.nyse.com/pdfs/section303Afaqs.pdf, accessed November 2005). Most companies from the NYSE sample chose to ignore all or some of the three conditions specified.

\section{Departure of Actual Disclosure from Recommendations and Guidelines}

It was found that most companies have failed to abide by the recommendations and guidelines suggested by various bodies in relation to financial reporting disclosure on their websites. The IASB has recommended that companies should set clear boundaries between audited and unaudited information. 
No such boundaries were clarified by a single company. Not a single company provided any notification of important changes to its website. Majority of the companies had disclaimers relieving the company of any responsibility of protecting the integrity of its website. A majority of the companies had vast differences between the financial statements' contents if presented in the local language and English. There was a lag of one to two years from the financial year end to the financial reports disclosed on the website for some companies.

The Web Trust's recommendation that companies provide assurance that all important information is up to date and available on their websites was not implemented by all the companies. In fact the disclaimers protected the companies from any litigation if information was to be incomplete or out dated.

The $\mathrm{COB}$ made similar recommendation of providing clear, precise and honest information on the websites. The major area of concern is the lack of complete information and clarification in relation to information as to whether it is audited or not.

Majority of the companies eagerly followed the recommendations made by the FASB of providing cautionary disclaimers and not providing links to analysts' websites.

The findings as well as literature review have demonstrated the point that financial reporting on the Internet is varied, in some circumstances considerably. These variations relate to scope, quality, completeness, as well as timeliness of financial reporting disclosure on the Internet. This can pose a problem as far as understandability and utilisation of information is concerned from the point of view of the user, for optimal decision-making.

\section{Recommendations to Improve Online Financial Reporting}

Based on the research and findings the following recommendations are proposed to improve financial reporting and disclosure on the Internet by companies:

- Base the financial reporting disclosure on the qualitative characteristics formulated by the IASB framework such as reliability, understandiblity, completeness, timeliness and verifiability of information. Ensure that online financial reports meet these characteristics,

- Release reports online at the same time as hard copy. The time frame should be based on individual country requirements,

- Provide audit reports in relation to all accounting information released on the website,

- Provide corporate governance disclosure based on internationally recognised guidelines,

- Provide a more user-friendly format for presentation of financial reports such as a Table of contents at the start of the report, with links to individual items. If interactive reports are used then a complete list of financial reports' items should be presented,

- Maintain the same content of reports in 'English version' of the reports as in the 'local' version. Provide the same depth and detail in the English version,

- All companies with online reporting disclosure should have brief surveys in relation to attaining views on the improvement of companies' websites from the users of the websites regarding content, quality and accessibility of information,

- The regulatory bodies and professional bodies as well as the large multinationals around the globe should work together on setting templates for companies to work with, therefore providing a uniform disclosure of financial reporting,

- Regulatory bodies should make the rule that companies with Internet presence should have the information verified by either an auditor from a well-known accounting body or at least a member of a professional body,

- Actual enforcement of mechanisms that are in place to improve quality of online financial reporting. 


\section{Conclusion}

The article provided insight into the disclosure aspects of financial reporting on the Internet. The analysis can be considered from different aspects including the preparer's viewpoint, the user's viewpoint, the regulators' viewpoint as well as other parties' viewpoints such as analysts. The factors identified in relation to various aspects of online financial reporting can be used by these parties to implement changes and put the recommendations provided in practice to make the Internet a better medium of information presentation and disclosure. As mentioned at the beginning, the literature has pointed in the direction of the Internet offering capabilities and potential for better and more useful financial reporting. The catch though is that it's not up to the Internet as a medium but rather the preparers (the companies) to utilise the capabilities offered to make the financial reporting online an enriching, benefiting and informed decision making process for the user.

\section{References}

Choi, F. \& Meek, G. 2005, International Accounting, Pearson Prentice Hall, New Jersey.

Commision des-Operations de Bourse (COB) Press Release May 1999, viewed July 2004, $<$ http://www.cob.fr/>

Cook, J. 1999, 'Information and Communication Technology: the Internet and Company Law', in ESRC Centre for Business Research, University of Cambridge.

Cucuzza, T.G. \& Cherian, J. 2001, 'The Internet and e-business: Trends and implications for the finance function.' Journal of Cost Management, vol.15, no.3,pp.5-14.

Financial Accounting Standards Board 2000, Business Reporting Research Project

Electronic Distribution of Business Reporting Information, viewed January 2004, $<$ http://www.fasb.org/news/memorandum.pdfs

Gray, G.L. \& Debreceny, R. 2001, Financial Reporting on the Internet - Instant, Economical, Global Communication, $<$ http://www.ifac.org/Library/>.

Jubb, P. Smith I.\& Haswell, S.2002, Company Accounting,Nelson, Melbourne.

Kaye, C \& Yuwono, J. 2002, Conglomerate Discount or Premium? How some diversified companies create exceptional value, Marakon Associates Research, viwed August 2003, $<$ http://www.marakon.com/ideas_pdf/id_030830_kaye.pdf $>$.

KPMG Global Sustainability Services, $200 \overline{5}, \mathrm{KPMG}$ International Survey of Corporate Responsibility Reporting viewed July 2004, <http://www.kpmg.com/>.

Litan, E.R. \& Wilson, P. 2000, 'Corporate Disclosure in the Internet Age', The Financial Times, 24th May 2000.

Lymer, A. Debreceny, R. Gray, G. \& Rahman, A. 1999, Business Reporting on the Internet, $<$ http://www.iasc.org.uk $>$.

Marston, C. \& Leow, C. 1998, 'Financial reporting on the Internet by leading U.K companies', paper presented to 21st Annual Congress of the European Accounting Association, Antwerp, Belgium.

New York Stock Exchange 2004, NYSE Listed Company Manual Section 303A Corporate Governance Listing Standards, viewed January $2005<\mathrm{http} / /$ www.nyse.com/pdfs/section303Afaqs.pdf $>$.

Radner, G. 2002, Best Practices in Online Corporate Governance Disclosure, CCBN, viewed February $2004<$ http://www.ccbn.com/_pdfs/whitepapers/>.

WebTrust2006, Overview of Trust Services, WebTrust and SysTrust, viewed January 2006, $<$ http://www.cpawebtrust.org/overview.htm>.

Wilson, M. \& Lombardi, R. 2001, 'Globalization and its discontents:The arrival of Triple BottomLine Reporting', Ivey Business Journal, September/October $2001,<\mathrm{http} / /$ www.iveybusinessjournal.com/view_article.asp?intArticle_ID=334>. 